\title{
Studies on Hill-Reaction in a Thermophilic Blue Green Alga, Cyanidium caldarium Geitler*
}

\author{
by Ikujirô FuKUDA**
}

Received August 11, 1962

The unicellular blue green alga, Cyanidium caldarium Geitler, represents one of the thermophilic forms of Cyanophyceae of wide distribution, often showing luxuriant growth in various hot springs in this country (Negoro, 1944 ${ }^{11}$ ). The organism is remarkable also in its acidophilic nature, tolerating even an acidity as extreme as $\mathrm{pH}$ 2.0 in its natural habitat. In a former contribution (Fukuda, 1958 ${ }^{2}$ ) a report has been made on the effects of some environmental factors upon the growth and physiolog1cal activities of this organism. In the present study, the activity of Hill-reaction in this alga was investigated, with special reference to the thermophilic and acidophilic natures of the organism.

\section{Materials and Methods}

The organism was grown under continuous bubbling with air containing $5 \% \mathrm{CO}_{2}$, in cotton plugged flasks on an inorganic medium of the following composition: $\mathrm{Ca}\left(\mathrm{NO}_{3}\right)_{2}, 0.5 \mathrm{~g} ; \mathrm{KH}_{2} \mathrm{PO}_{4}, 0.2 \mathrm{~g} ; \mathrm{MgSO}_{4} \cdot 7 \mathrm{H}_{2} \mathrm{O}, 0.2 \mathrm{~g} ; \mathrm{FeCl}_{2}$, trace; $\mathrm{H}_{2} \mathrm{SO}_{4}(1 \mathrm{~N}), 10 \mathrm{ml}$; distilled water, $1,000 \mathrm{~m} l(\mathrm{pH}: 2.4)$. The intensity of illumination was ca. 10,000 lux; temperature of water bath kept at $45^{\circ}$.

Algal cells harvested were washed three times by centrifugation with hot, dis-

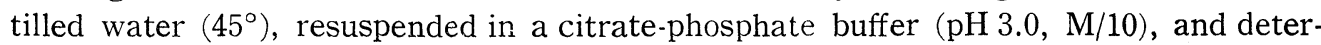
mined the metabolic activities. Usually 10-day old cultures of the alga were used unless otherwise stated. The rate of gas exchange was measured with a Warburg manometer, usually at $45^{\circ}$, using 5 to $10 \mathrm{ml}$ of suspension containing about 50 to $100 \mathrm{mg}$ dry weight of algal cells.

The rate of Hill-reaction was determined by measuring the volume of oxygen evolved in a nitrogen gas atmosphere under illumination of 50,000 lux with incandescent lamps. In this reaction, various hydrogen acceptors, mostly $p$-quinone, and sometimes the Hill Mixture, 2, 6-dichlorophenol indophenol etc., were used as Hill oxidants. When necessary, a $20 \%-\mathrm{KOH}$ solution and yellow phosphorus were used as absorbents for eliminating $\mathrm{CO}_{2}$ and $\mathrm{O}_{2}$. The velocity of Hill-reaction was expressed as the rate of $\mathrm{O}_{2}$-evolution per unit dry weight of algal cells $(\mathrm{ml} / \mathrm{g}$ alg./hr.), or as the rate of $\mathrm{O}_{2}$-evolution per chlorophyll $(\mathrm{ml} / \mathrm{g}$ chl./hr.). The chlorophyll content was measured electrophotometrically on the $80 \%$ acetone extract of algal cells, using a filter for $660 \mathrm{~m} \mu$ wave length.

The photosynthetic activity was determined by measuring the volume of oxygen evolved in the air containing $5 \%$ of $\mathrm{CO}_{2}$, corrections for respiratory oxygen uptake being made by simply subtracting the values for gas absorption in the light. The intensity of illumination was 50,000 lux, as in the case of the Hill-reaction.

The respiratory activity was estimated by measuring the gas uptake in air, in

* This work was supported by the Grant in Aid of Scientific Research of the Ministry of Education.

** Department of Biology, Faculty of Science, Tokyo College of Science, Kagurazaka, Shinjuku-ku, Tokyo, Japan. 
dark, and in the presence of $20 \% \mathrm{KOH}$ solution.

\section{Results and Discussion}

Effect of temperature on rate of Hill-reaction: The rates of Hill-reaction at various temperatures measured with $p$-quinone as the Hill oxidant are shown in Fig. 1. The initial rate of $\mathrm{O}_{2}$-evolution during the first 15 minutes of incubation was used for computing the reaction rate, since a more or less marked decrease in the reaction rate was always inevitable in later periods of incubation. It will be seen from the figure that the optimum temperature range of Hill-reaction lies as high as $50^{\circ}$ to $55^{\circ}$. Above this optimum, a rapid decrease in the reaction rate occurs, most probably due to the irreversible heat-denaturation of the reaction system. The reaction rate, on the other hand, becomes almost insignificant below $30^{\circ}$, a temperature range still adequate for the metabolic reactions of ordinary mesophillic forms ${ }^{3)}$.

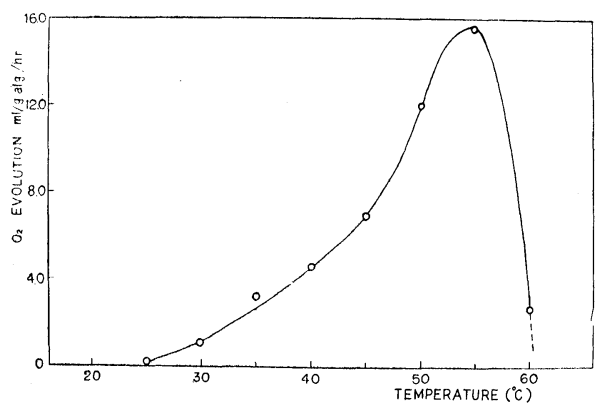

Fig. 1. Rate of Hill-reaction of Cyanidium caldarium Geitler, as influenced by reaction temperature. ( $\mathrm{pH} 3.0$; Intensity of illumination, 50,000 lux; Hill oxidant, $p$ quinone).

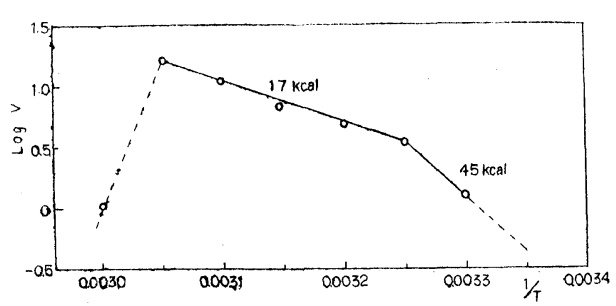

Fig. 2. Rate of Hill-reaction of Cyanidium caldarium Geitler, as influenced by reaction temperature. Arrhenius-plot of the data in Fig. 1; $\log \mathrm{V}$, logarithm of the rate of Hill-reaction ( $\mathrm{ml} / \mathrm{g}$ alg. dry weight/hr.); $\mathrm{pH}$, 3.0 ; intensity of illumination, 50,000 lux; Hill oxidant, $p$-quinone)

In Fig. 2, the logarithms of the rates of Hill-reaction ( $\log \mathrm{V}$ in the figure) are plotted against the reciprocals of absolute temperature $(1 / T)$. From the dip of the straight portion of the Arrhenius plot shown in the figure, the apparent heat of activation $\left(\Delta \mathrm{H}^{*}\right)$ for the "Hill-reaction" was computed to be as follows.

$$
\begin{aligned}
& \Delta \mathrm{H}^{*}=17 \mathrm{Kcal}\left(55^{\circ} \sim 35^{\circ}, \mathrm{pH} 3.0\right) \\
& \Delta \mathrm{H}^{*}=45 \mathrm{Kcal}\left(35^{\circ} \sim 30^{\circ}, \mathrm{pH} 3.0\right)
\end{aligned}
$$

The highly thermophilic behavior of the alga toward high temperature is in general accord with the results of the previous study on growth, respiration and photosynthesis of the same organism ${ }^{21}$. The optimum temperature for Hill-reaction in the present study nearly equals to that for photosynthesis and respiratory $\mathrm{O}_{2}$-uptake. The same is also true with the apparent activation energy for the Hill-reaction (see above) and photosynthesis*. A similarly steep drop in activity in the suboptimal temperature range (about $30^{\circ}$ and below) corresponding to an apparent activation energy of $45 \sim 70 \mathrm{Kcal}$ is also common to the two processes.

Effect of hydrogen ion concentration on the rate of Hill-reaction: The values for the rate of Hill-reaction at various pH's are presented in Table 1, showing the high-

* Apparent activation energy for photosynthesis in Cyanidium caldarium Geitler (light saturation, $\mathrm{CO}_{2} 0.1 \%$ ).

$$
\begin{aligned}
& \Delta \mathrm{H}^{*}=17 \mathrm{Kcal}\left(55^{\circ} \sim 40^{\circ}, \mathrm{pH} 3.0\right) \\
& \Delta \mathrm{H}^{*}=7 \mathrm{Kcal}\left(40^{\circ} \sim 30^{\circ}, \mathrm{pH} 3.0\right)
\end{aligned}
$$

(Fukuda 1958) 
ly acidophilic property, characteristic of this organism. The dependency toward $\mathrm{pH}$ in this case, however, seems to be less pronounced than in the case of photosynthesis reported in the previous paper ${ }^{2}$.

Table 1. Rate of Hill-Reaction at various pH's (Reaction rate, $\mathrm{O}_{2}$-evolved $\mathrm{ml} / \mathrm{g}$ dry weight $/ \mathrm{hr}$.)*.

\begin{tabular}{c|c|c|c|c} 
Temperature & pH 3.0 & $\mathrm{pH} 4.0$ & $\mathrm{pH} 5.0$ & $\mathrm{pH} 7.0$ \\
$30^{\circ}$ & 1.09 & 1.03 & 0.95 & 0.85 \\
$35^{\circ}$ & 3.29 & 3.07 & 2.85 & 2.50 \\
$40^{\circ}$ & 4.50 & 4.30 & 3.75 & 3.42 \\
$45^{\circ}$ & 6.52 & 6.25 & 5.55 & 5.00 \\
$50^{\circ}$ & 12.3 & 11.5 & 10.5 & 9.55 \\
$55^{\circ}$ & 16.0 & 15.5 & 14.3 & 13.0 \\
\hline
\end{tabular}

* Condition of measurement: Temperature, $45^{\circ}$; intensity of illumination, $50,000 \mathrm{Lux}$; gas atmosphere, nitrogen gas (20\% $\mathrm{KOH}$ solution in center well); Hill oxidant, $p$-quinone $\left(3 \times 10^{-3} \mathrm{M}\right)$; citrate-phosphate buffer $\mathrm{M} / 10(\mathrm{pH} 3.0 \sim 7.0)$.

In view of the above-described findings, the following experiments were carried out at $\mathrm{pH} 3.0$, and $45^{\circ}$ if not otherwise stated.

Hill-reaction in presence of various Hill oxidants: The Hill-reaction in this organism was tested with various substances as the Hill oxidants; $p$-quinone $\left(3 \times 10^{-3} \mathrm{M}\right)$, "Hill mixture " 4,5 ) (K-ferrioxalate $5 \times 10^{-2} \mathrm{M}$, K-ferricyanide $2 \times 10^{-3} \mathrm{M}$, ferri-ammonium sulfate $\left.1 \times 10^{-3} \mathrm{M}\right)$; chromic oxalate $\left(1 \times 10^{-2} \mathrm{M}\right) ; 2$, 6-dichlorophenol indophenol $(3 \times$ $10^{-5} \mathrm{M}$ ). The results obtained are shown in Fig. 3. As will be seen from the curves

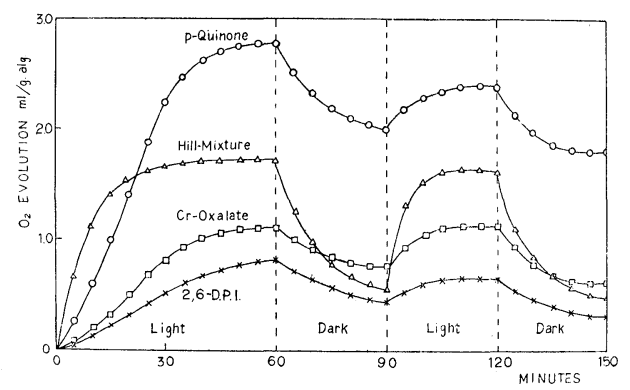

Fig. 3. Time course of Hill-reaction in Cyanidium caldarium Geitler, as influenced by various Hill oxidants. ( $\mathrm{pH} 3.0 ; 45^{\circ}$; Intensity of llumination, 50,000 lux)

in the figure, the most rapid rate of Hill-reaction was obtained with the "Hill mixture". $p$-Quinone was found to be almost equally efficient. Less rapid was the reaction with Cr-oxalate and 2,6-DPIP* as the oxidant. As has already been stated, there occurred in most cases a more or less marked drop in reaction rate at later periods of reaction, the $\mathrm{O}_{2}$-time-curve attaining a plateau before reaching the theoretical level (see Fig. 3 and Table 2). The values for the initial reaction rate and the amount of $\mathrm{O}_{2}$ evolved in 60 minutes of illumination are summarized in Table 2. The highest rate of $\mathrm{O}_{2}$ evolution was obtained when $p$-quinone was used as the oxidant. On alternate applications of light and dark, evolution of molecular oxygen was observed at each light period, thus suggesting that the cessation of $\mathrm{O}_{2}$-evolution in the light period is not due to the irreversible damage of the Hill-reaction system (Fig. 3).

The use of chromic oxalate** $\left(\mathrm{Na}_{3} \mathrm{Cr}\left(\mathrm{C}_{2} \mathrm{O}_{4}\right)_{3} \cdot 3 \mathrm{H}_{2} \mathrm{O}\right)$ in this experiment is deter-

* Abbreviation, DPIP: 2, 6-dichlorophenol indophenol.

** The author wishes to express his cordial thanks to Prof. M. Iguchi of Tokyo College of Science for the supply of pure samples of the complex salts. 
Table 2. Rates of Hill-reaction in Cyanidium caldarium Geitler in the presence of various substances as Hill oxidant.

(Reaction rate: $\mathrm{O}_{2}$-evolved $\mathrm{ml} / \mathrm{g}$ alg. dry weight $/ \mathrm{hr}$.)*

\begin{tabular}{l|c|c}
\hline Hill oxidants & Initial velocity & $\begin{array}{c}\text { Maximum amounts of } \mathrm{O}_{2} \\
\text { evolved in } 60 \text { minutes } \\
(\% \text { of theory })\end{array}$ \\
\hline$p$-quinone & 6.9 & $60.7 \%$ \\
Hill mixture & 8.0 & 36.5 \\
Cr-oxalate & 1.7 & 23.7 \\
2, 6-DPIP & 0.9 & 17.8 \\
\hline
\end{tabular}

* Condition of measurement: Temperature, $45^{\circ}$; Intensity of illumination, 50,000 lux; Gas phase, nitrogen gas atmosphere, $(20 \% \mathrm{KOH}$ solution in center well); citrate-phosphate buffer $\mathrm{M} / 10$ ( $\mathrm{pH} 3.0)$; concentration of each Hill oxidants, see text.

mined as a result of a tentative search for new substances which $\mathrm{m} y$ serve as the Hill oxidant. It has to be noted in this connection that Hatchett and Marcus ${ }^{6)}$ have obtained a sufficiently high reaction rate, in the case of leaf chloroplasts, with another metal complex, Cobaltioxalate $\left(\mathrm{K}_{3} \mathrm{Co}\left(\mathrm{C}_{2} \mathrm{O}_{4}\right)_{3}\right)$ as the Hill oxidant.

Effect of various inhibitors on the Hill-reaction: The effects of various inhibitors on the Hill-reaction are summarized in Fig. 4 and Table 3. In these experiments, $p$ quinone $\left(3 \times 10^{-3} \mathrm{M}\right)$ was employed as the Hill oxidant. In Fig. 4, the degree of inhibition $(I)$ was plotted against the logarithms of inhibitor concentration $[p]$. The

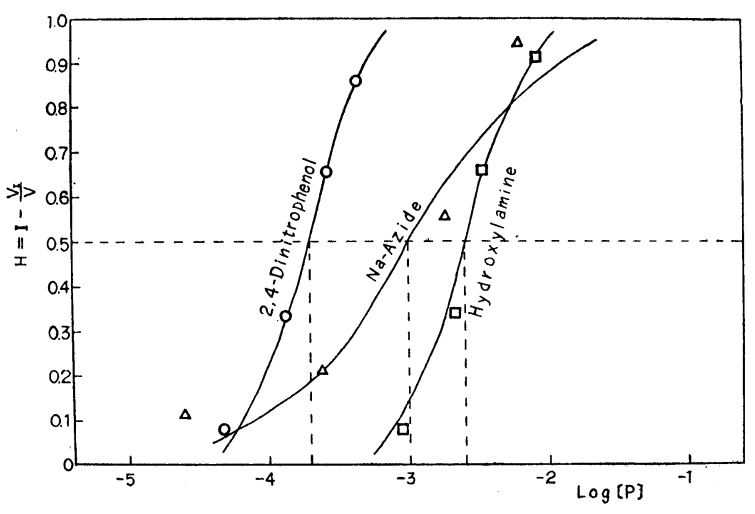

Fig. 4. Effect of inhibitors on Hill-reaction of Cyanidium caldarium Geitler (intact cells). ( $\mathrm{pH} 3.0 ; 45^{\circ}$; Intensity of illumination, 50,000 lux.)

Table 3. Inhibition constant and "order" of sygmoid curve of inhibition.

\begin{tabular}{l|c|c}
\multicolumn{1}{c|}{ Inhibitors } & $-\log _{10} \Phi_{p}$ & Order of inhibition \\
\hline hydroxylamine & 2.6 & 2 \\
Na-azide & $(3.0)$ & $(1)$ \\
2, 4-dinitrophenol & 3.7 & 2 \\
\hline
\end{tabular}


curves in the figure were drawn according to the formula for a sygmoid curve* of inhibition, assuming an n-value of unity for the case of sodium azide, and 2 for the cases of hydroxylamine and 2,4-dinitrophenol. In the latter two the fitness of theoretical curve with the experimental data seems to be satisfactory. The fluctuations encountered in the case of sodium azide is not accounted for. The values for $\phi_{P}$, the inhibition constant, and n, the "order" of sygmoid curve, are presented in Table 3. The "second order" inhibition with hydroxylamine (and 2, 4-dinitrophenol) will be worth noticing since the rather unfrequent type of inhibition has also been observed in photosynthesis and related reactions. The results of the present study is also in harmony with the findings of Huzisige ${ }^{7)}$ who has investigated the inhibition of Hill-reaction, using Chlorella and spinach chloroplast.

The values of $\phi_{p}$, which represent (the reciprocals of) the apparent affinity of the poison toward the catalyst, however, differs largely from the previous data for Chlorella and spinach. A wide difference in $\mathrm{pH}$ ranges studied may be the cause of such deviation.

Effect of heat-treatment on the Hill-reaction, photosynthesis and respiration: The algal cells were subjected for 10 minutes to a heat-treatment** at $60^{\circ}$. The heated cell suspension was rapidly cooled and tested for the activities of Hill-reaction, photosynthesis and respiration (control: untreated cells).

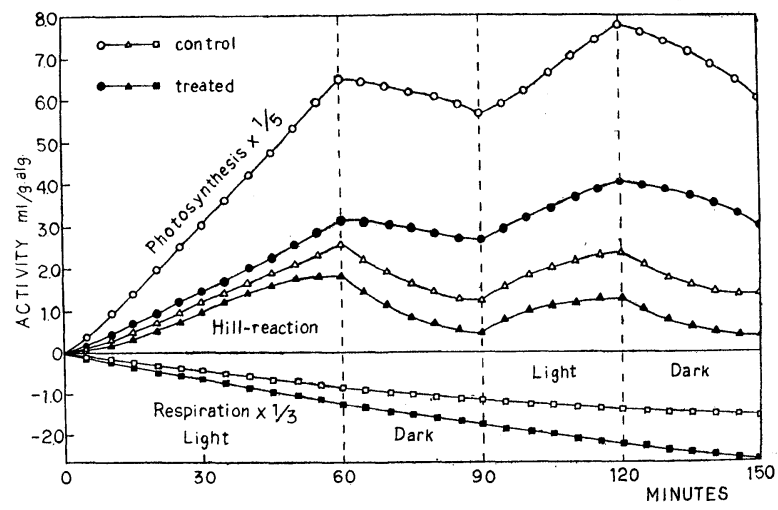

Fig. 5. Effect of heat-treatment on the Hill-reaction, photosynthesis and respiration in Cyanidium caldarium Geitler; heat-treatment, $60^{\circ}$, 10 minutes ; $\mathrm{pH}, 3.0$; temperature, $45^{\circ}$; intensity of illumination, 50,000 lux. Respiration was always measured in the dark.

The results are presented in Fig. 5, showing the most marked heat-inactivation of photosynthesis. Less marked was the inhibition of Hill-reaction, a fact probably reflecting the less complicated constitution of the reaction system in this case as compared with the complete reaction system of photosynthesis. In marked contrast to these processes, the respiratory activity (endogenous) of the cells were found to be significantly accelerated. In this connection it will also be noted that the catalase activity of the algal cells are also significantly accelerated by heat-treatment. The heat-activation of catalase reaction is not a rare thing (e.g., heat activation of catalase in a thermophilic bacterium has recently been investigated by Nakamura ${ }^{8)}$ ).

* The sygmoid curve of inhibition: $\quad I=\frac{1}{1+\left(\frac{\phi_{p}}{[p]}\right)^{n}}$ where $\boldsymbol{I}$ represents the degree of inhibition, $\Phi_{p}$ constant of poisoning, and $[p]$ concentration of the poison, the constant $n$ is definding the order of the sygmoid curve.

** Heat-treatment was carried out in a citrate-phosphate buffer $1 / 20 \mathrm{M}$ (pH 5). Conditions for tests of other metabolic activities, see text. 
Activities of the Hill-reaction, photosynthesis and respiration in cell homogenates: The effects of disrupting the cell-structure were studied as follows. Cell homogenate was prepared by grinding the cells with quarz sand for about 30 minutes in a $M / 10$

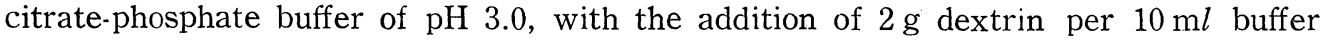
solution. The homogenate obtained was fractionated by repeating differential centrifugation at 2,000 r.p.m. for 2 minutes, and the supernatant of the 7 th centrifugation was used for the metabolic tests. Subsequent centrifugation of this supernatant for about 30 minutes at 2,000 r.p.m. gave rise to a clear blue supernatant containing phycocyanin, and the precipitate of chromatophores containing chlorophyll and carotenoids.

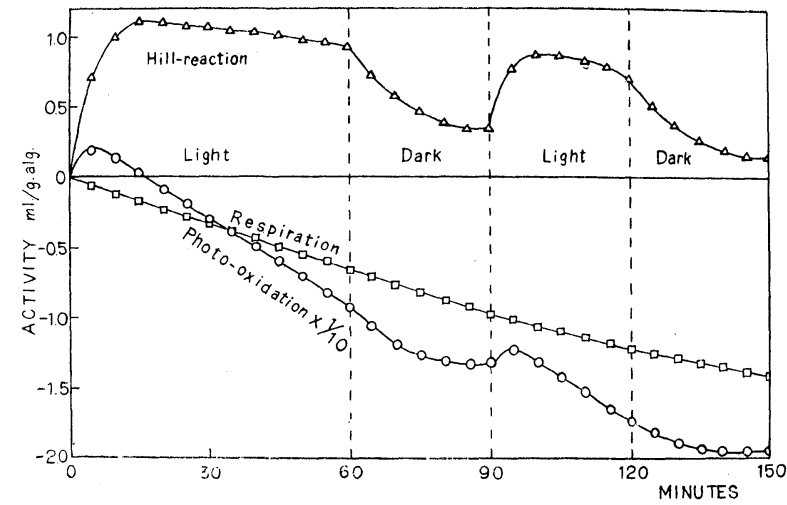

Fig. 6. Hill-reaction, photooxidation and respiration in cell homogenates of Cyanidium caldarium Geitler; $\mathrm{pH}, 3.0 ; 45^{\circ}$; intensity of illumination, 50,000 lux. Respiration was always measured in the dark.

The experimental results are shown in Fig. 6. The rate of Hill-reaction per unit amount of chlorophyll was found to have decreased to one-third that of intact cells. The photosynthetic activity was found to be completely abolished. On incubating the homogenate in an atmosphere containing $5 \% \mathrm{CO}_{2}$, there occurred, after 10 minutes of induction period (or even a slight burst of gas evolution-see Fig. 6), a rapid gasuptake, which was, however, found to depend on the light. The change observed was, therefore, interpreted to represent the photooxidation of some endogenous substance in the algal cell.

The respiratory activity, on the other hand, was found to be remaining unimpaired the cell homogenate, although the $\mathrm{Qo}_{2}$ value diminished to one-third that of the inact cells.

Throughout the above-described experimental results, the most marked point of interest will be the sensitiveness of photosynthetic activity towards various treatments, including heat-treatment and disruption of cell structure. The relatively high stability of the Hill-reaction system in this respect will also be noted. The respiratory system belongs to the most refractile of the metabolic activities tested. These findings are in general accord with the results of our previous study.

\section{Summary}

1) The metabolic activities of a thermo- and acidophilic blue green alga, Cyanidium caldarium Geitler, were investigated with special reference to its phototrophic activities, photosynthesis and Hill-reaction.

2) The organism utilizes as the Hill oxidants, various substances including Hill mixture, p-quinone, Cr-oxalate and 2,6-DPIP, in the order of decreasing rate of reac- 
tion.

3) The temperature dependency of the Hill-reaction in this organism was investigated. The optimum temperature of the reaction was found to lie at $50^{\circ}$ to $55^{\circ}$ the reaction rate showing a sharp drop on either side of this maximum point. The reaction rate was found to be makedly suppressed even at the range of moderate temperatures favorable for the ordinary mesophills (around $30^{\circ}$ ), and there was no detectable activity of the Hill-reaction at $25^{\circ}$.

4) The apparent activation energy for the Hill-reaction in this organism was found to be $17 \mathrm{Kcal}$ (between $55^{\circ} \sim 35^{\circ}$ ), and about $45 \mathrm{Kcal}$ (between $35^{\circ} \sim 30^{\circ}$ ).

5) The heat-stability of metabolic activities of the algal cells were compared. The photosynthesis and Hill-reaction were found to be affected by the heat treatment at $60^{\circ}$ (10 minutes) by about $50 \%$ and $30 \%$, respectively. On the contrary, the respiratory oxygen uptake was accelerated by about $50 \%$ by same heat-treatment.

6) The cell homogenate was found to retain the capacity for the Hill-reaction. No activity of photosynthesis was detected in the cell homogenate.

The author wishes to express his cordial thanks to Prof. H. Tamiya, and Prof. A. Takamiya of University of Tokyo, for their kind guidance and encouragement. Thanks are also due to Prof. H. Huzisige of Okayama University and Prof. M. Iguchi of this College for discussions throughout the work.

\section{References}

1) Negoro, K., Sci. Rep. Tokyo Bunrika Daigaku B 101: 232 (1944). 2) Fukuda, I., Bot. Mag. Tokyo, 71: 79 (1958). $\quad 3$ ) Rabinowitch, E. I., Photosynthesis and Related Process. Interscience Pub. Inc., N.Y. p. 1544 (1956). 4) Hill, R., Nature 139: 881 (1937);Proc. Roy. Soc., B127:192 (1939). 5) Hill, R. and Scarisbrick, R., Proc. Roy. Soc., B 129: 238 (1940); Nature, 146:61 (1940). 6) Hatchett, J. L., and Marcus, R. H., Arch. Bioch. Bioph., 76: 233 (1958). 7) Huzisige, H., Jour. Bioch. Tokyo 41: 605 (1954). $\quad$ 8) Nakamura, Y., J. Bioch. 48: 295 (1960).

\section{摘 要 \\ 福田育二郎： 温泉性ラン藻，イデュコゴメのヒル反応に関する研究}

1）好熱性特よび好酸性のラン藻である，Cyanidium caldarium Geitler の代謝系のうち，とくに光 と関係のある, 光合成扮よびヒル反応について, その活性度を比較検討した。

2) この藻細胞のヒル反応活性を，ヒル混液， $p$-キノン，しゅ5酸第二クロム，2，6-DPIP，など種々 の試薬をヒル反応試薬に用いて测定し，その反応速度を比較検討した。 さらに種々の阻害剤によるとル反 応の阻害現象を解析した。

3) この藻細胞のヒル反応の温度依存性について検討した。 この反応の至適温度域は $50^{\circ} \sim 55^{\circ}$ にあっ た.

4) この藻細胞のヒル反応の見か忷の活性化エネルギーは, $17 \mathrm{Kcal}\left(55^{\circ} \sim 35^{\circ}\right)$ 拈よび, ほぼ $45 \mathrm{Kcal}$ $\left(35^{\circ} \sim 30^{\circ}\right)$ と計算される。通常の緑葉に招いて適当な温度域 $\left(30^{\circ}\right.$ 近辺)でも, 著しい活性の低下が浔めら れ，250ではほとんどヒル反応は見られなくなる。

5）この藻細胞の代謝活性の熱に対する安定性が比較検討された。光合成，ヒル反応は $60^{\circ}, 10$ 分間の 熱処理によって，それぞれ $50 \%$ ，30\% 阻害され，呼吸は $50 \%$ 促進された。

6) 細胞磨砕物は，な洛 $1 / 3$ 程度のヒル反応活性を有するが，光合成活性は完全に失われた。（東京理科 大学理学部生物学教室) 